\title{
Research on Evaluation Model of Department Responsibilities Conflict Based on DRCI
}

\author{
Xiaosong Li*, Zenghua Li, Tong Liu, Junlei Hao \\ No.26 Fucheng Road Haidian District, Beijing, China 100142 \\ ${ }^{*}$ Corresponding author
}

\begin{abstract}
The definition of department responsibility conflict evaluation is first given in the paper. Following the analysis of the evaluation process, which is generalized to assess extent of the responsibility conflict among different power departments, the department responsibility matrix is established and the construction of the evaluation model is presented. Then an application case is introduced to illustrate the progress and the methodology of department responsibilities conflict evaluation. The conclusion of the research may build a sound foundation for optimizing department responsibilities.
\end{abstract}

Keywords-brief list of responsibilities; department responsibility conflict; evaluation model

\section{INTRODUCTION}

The responsibility boundaries are sometimes unclear among different power branches. There are also such pheromones as in consistences between power and responsibilities, conflicts among responsibilities, and the abuses of power. In order to effectively solve these realistic problems, this paper construct the model of department responsibilities conflict based on DRCI (Department Responsibilities Conflict Index). The conclusion may build a good theoretical and methodological foundation for evaluating department responsibilities conflict.

Department responsibilities is defined as the scope of duty and the tasks to be assumed in order to fulfill the responsibilities of an organization, as well as the corresponding responsibilities for accomplishing these tasks. Conflict is defined as contradictions, strife and disputes. The department responsibilities conflict evaluation is defined as making the department responsibilities optimization as the goal, used the scientific and feasible methods for giving objective, fair and systematic value judgment to the department responsibilities conflict and related problems, based on full information of department responsibilities .

Department responsibilities conflict evaluation process is shown in Figure 1.

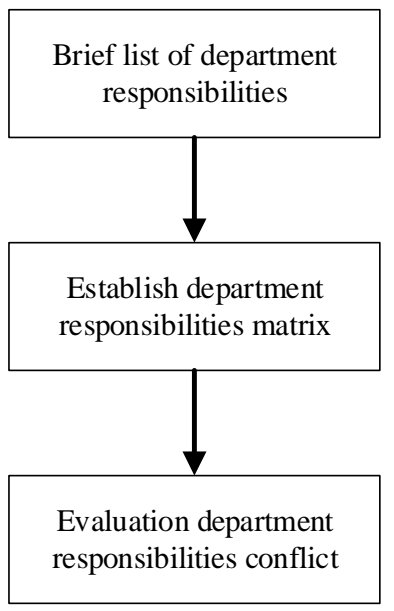

FIGURE I. DEPARTMENT RESPONSIBILITIES CONFLICT EVALUATION PROCESS

1. Brief list of department responsibilities. According to the department tasks, break down department responsibilities by the method of work breakdown structure, established the department responsibilities list, explicit "responsibility family property" of department. At the same time, draw "responsibility boundary" and "behavior boundaries".

2. Establish department responsibilities matrix. Establish department responsibilities matrix between departments, described two departments as row vector and column vector respectively.

3. Evaluation department responsibilities conflict. According to the evaluation standard, used experts survey method to evaluate the conflict between the predicate, attributive, object, and range of department responsibilities. On this basis, calculated the value of department responsibilities conflict.

\section{DEPARTMENT RESPONSIBILITY EVALUATION MODEL}

According to the department responsibilities conflict evaluation process, analyzed the evaluation model.

\section{A. Combing the List of Department Responsibilities}

Combing department responsibilities established department responsibilities list, and decomposed department responsibilities into predicates, attributive, object and range, which are shown in Table I. The predicate is defined as describe the subject, how the subject is or what it is. The attributive is defined as modified components of the name, 
which indicate the name by owner, nature, quantity, etc. The object is subject to verb, indicated the person or thing involved in the action. The range is defined as the action target of a person or thing. For example, the A department original responsibility of company is described as: "responsible for the department document file management.” Then, the predicate of this responsibility described as: "Responsible"; the attributive of this responsibility described as: "Document file"; the object of this responsibility described as: "Management"; the range of this responsibility described as: "A department”.

TABLE I. DEPARTMENTAL RESPONSIBILITIES LIST

\begin{tabular}{|c|c|c|c|c|c|c|c|}
\hline \multirow[b]{2}{*}{ No. } & \multirow[b]{2}{*}{$\begin{array}{c}\text { Res } \\
\text { pons } \\
\text { ibilit } \\
\text { y } \\
\text { Subj } \\
\text { ect } \\
\end{array}$} & \multirow[b]{2}{*}{$\begin{array}{c}\text { Res } \\
\text { pons } \\
\text { ibilit } \\
y \\
\text { Basi } \\
\text { s } \\
\end{array}$} & \multicolumn{3}{|c|}{ Responsibility Describe } & \multirow[b]{2}{*}{$\begin{array}{c}\mathrm{Ra} \\
\mathrm{ng} \\
\mathrm{e}\end{array}$} & \multirow[b]{2}{*}{$\begin{array}{c}\text { Joint } \\
\text { Impleme } \\
\text { ntation } \\
\text { of The } \\
\text { Main } \\
\text { Body }\end{array}$} \\
\hline & & & $\begin{array}{c}\text { Respon } \\
\text { sibility } \\
\text { Predicat } \\
\text { e }\end{array}$ & $\begin{array}{l}\text { Responsi } \\
\text { bility } \\
\text { Attributiv } \\
\text { e }\end{array}$ & $\begin{array}{c}\text { Respo } \\
\text { nsibili } \\
\text { ty } \\
\text { Objec } \\
\text { t } \\
\end{array}$ & & \\
\hline $\begin{array}{l}\text { Fill } \\
\text { in } \\
\text { Des } \\
\text { crip } \\
\text { tion }\end{array}$ & $\begin{array}{l}\text { 1.Res } \\
\text { sector } \\
\text { 2.Res } \\
\text { the hi } \\
\text { 3.Res } \\
\text { objec } \\
\text { 4.Ran } \\
\text { 5.Joir } \\
\text { respo }\end{array}$ & $\begin{array}{l}\text { asibil } \\
\text { ar aut } \\
\text { nsibil } \\
\text { resp } \\
\text { is def } \\
\text { mplen }\end{array}$ & $\begin{array}{l}\text { Basis is } \\
\text { ities; } \\
\text { Describe } \\
\text { ibility; } \\
\text { d as the } \\
\text { tation of } \\
\text { the main }\end{array}$ & $\begin{array}{l}\text { ject of res } \\
\text { he Main B } \\
\text { nplementat }\end{array}$ & $\begin{array}{l}\text { ibiliti } \\
\text { is def } \\
\text { by a r }\end{array}$ & $\mathrm{ut}$ & $\begin{array}{l}\text { the } \\
\text { igned by } \\
\text { and } \\
\text { subjects. }\end{array}$ \\
\hline
\end{tabular}

\section{B. Establish Department Responsibilities Matrix}

In this paper, two departments responsibilities are described as row vector and column vector, established predicate matrix, attributive matrix, object matrix, range matrix and responsibilities matrix of two departments .The department responsibilities matrix is $\mathrm{n} \times \mathrm{m}$ matrix, which are shown in Table II. It consists rows, columns, and elements. The rows shown specific responsibilities of department b; The columns show $\mathrm{m}$ specific responsibilities of department $\mathrm{a}$.

TABLE II. DEPARTMENTS RESPONSIBILITY MATRIX

\begin{tabular}{|c|c|c|c|c|}
\hline $\begin{array}{c}\text { Department a } \\
\text { Departmentb }\end{array}$ & $\begin{array}{c}\text { Responsibility } \\
\mathbf{1}\end{array}$ & $\begin{array}{c}\text { Responsibility } \\
\mathbf{2}\end{array}$ & $\mathbf{\cdots} \cdot \mathbf{. .}$ & $\begin{array}{c}\text { Responsibility } \\
\mathbf{m}\end{array}$ \\
\hline Responsibility 1 & & & & \\
\hline Responsibility 2 & & & & \\
\hline$\ldots .$. & & & & \\
\hline Responsibility $\mathbf{n}$ & & & & \\
\hline
\end{tabular}

\section{Department Responsibilities Conflicts Evaluation}

Invite experts to evaluate the responsibilities conflict of predicate, attributive, object, and range between two departments, and then calculate the value of department responsibilities conflict[1].

\section{1) Predicate Conflict Evaluation}

The conflict value of each element i n the predicate conflict matrix is calculated by:

$$
l(i j)=\frac{\sum_{k=1}^{n} l(i j)_{k}}{n}
$$

l(ij) show the predicate conflict value of $i$ th row, $j$ th column, ${ }^{l(i j)_{k}}$ show the predicate conflict value of $i$ th row, $j$ th column by kth expert, $n$ show the number of experts.

$l(i j)_{k}$ had three levels: No conflict, general conflict, big conflict, the corresponding quantitative values are: 0,0.5,1. Similarly, get the conflict value of attributive, object and range, which are shown by ${ }^{m(i j)}$, ${ }^{(i j)}$, ${ }^{(i j)}$ respectively.

\section{2) Department Responsibilities Conflict Evaluation}

According to the conflict value of elements about the responsibility matrix, the attributive matrix, the object matrix and the range matrix, used following equation to get conflict values of elements about department responsibilities matrix:

$$
c(i j)=Z(i j) \times\left(w_{1} \times l(i j)+w_{2} \times m(i j)+w_{3} \times n(i j)+w_{4} \times p(i j)\right)
$$

$c(i j)$ show the conflict value of the $i$ th row and $j$ th column, ${ }^{W_{1}},{ }^{W_{2}},{ }^{W_{3}}$ and ${ }^{W_{4}}$ show the weight of the responsibility predicate conflict, the responsibility attributive conflict, the responsibility object conflict and the responsibility range conflict respectively. $Z(i j)$ means the adjustment factor, the value of $Z(i j)$ is 0 or 1 , when the ${ }^{l(i j)}, m(i j), n(i j), p(i j)$ any value is 0 (no conflict), the value of $Z(i j)$ is 0 , and the other case the value of $Z(i j)$ is 1 .

According to the conflict value of elements about responsibility matrix, the value of responsibility conflict evaluation is obtained by following[2]:

$$
c_{a b}=\frac{\sum_{i=1}^{m} \max c(i j)+\sum_{j=1}^{n} \max c(i j)}{i+j}
$$

$c_{a b}$ show the value of responsibilities conflict evaluation between department a and department b, ${ }^{c(i j)}$ show the conflict value of the ${ }^{i}$ th row and ${ }^{j}$ th column.

\section{3) Conclusion of Department Responsibilities Conflict} Evaluation

The conclusions of department responsibilities conflict evaluation include quantitative conclusion and qualitative conclusion.

\section{Quantitative Conclusions}

According to the equation 3, get the conclusion of department responsibilities conflict quantitative evaluation.

\section{Qualitative Conclusions}

Assuming that there are four types of department responsibilities conflict qualitative evaluation conclusions: no conflict, small conflict ,general conflict ,big conflict, The corresponding evaluation criteria $E=\left\{e_{1}, e_{2}, e_{3}, e_{4}\right\}=$ no conflict, small conflict ,general conflict ,big conflict $\}=\{0,0.15,0.6,0.9\}$. The qualitative evaluation conclusion of department responsibilities conflict is calculated by following equation[3]: 


$$
l_{i}=\frac{1-\left|c-e_{i}\right|}{\sum_{i=1}^{4}\left[1-\left|c-e_{i}\right|\right]}, i=1,2,3,4
$$

evaluated department responsibilities conflict between these two departments.

\section{CASE STUDY}

In this paper, used the administrative department and the development department of A company as an example,

\section{A. Combing the List of Department Responsibilities}

A list of administrative department responsibilities is shown in Table III.

TABLE III. A LIST OF ADMINISTRATIVE DEPARTMENT RESPONSIBILITIES

\begin{tabular}{|c|c|c|c|c|c|c|c|}
\hline \multirow[b]{2}{*}{ No. } & \multirow[b]{2}{*}{$\begin{array}{l}\text { Responsibility } \\
\text { Subject }\end{array}$} & \multirow[b]{2}{*}{ Responsibility Basis } & \multicolumn{3}{|c|}{ Responsibility Describe } & \multirow[b]{2}{*}{ Range } & \multirow{2}{*}{$\begin{array}{c}\text { Joint } \\
\text { Implementation } \\
\text { of the Main Body }\end{array}$} \\
\hline & & & $\begin{array}{l}\text { Responsibili } \\
\text { ty Predicate }\end{array}$ & $\begin{array}{l}\text { Responsibility } \\
\text { Attributive }\end{array}$ & $\begin{array}{l}\text { Responsibilit } \\
\text { y Object }\end{array}$ & & \\
\hline 1 & $\begin{array}{c}\text { Administrative } \\
\text { Department }\end{array}$ & $\begin{array}{l}\text { Take the lead in writing the } \\
\text { company development strategy }\end{array}$ & Lead & $\begin{array}{c}\text { Company } \\
\text { Development Strategy }\end{array}$ & Write & Company & None \\
\hline 2 & $\begin{array}{l}\text { Administrative } \\
\text { Department }\end{array}$ & $\begin{array}{c}\text { Responsible for formulating } \\
\text { company policies and regulations }\end{array}$ & Responsible & $\begin{array}{l}\text { Company Policies And } \\
\text { Regulations }\end{array}$ & Formulate & Company & None \\
\hline 3 & $\begin{array}{l}\text { Administrative } \\
\text { Department }\end{array}$ & $\begin{array}{c}\text { Responsible for company } \\
\text { administration logistics and } \\
\text { external relations } \\
\end{array}$ & Responsible & $\begin{array}{c}\text { Administration } \\
\text { Logistics }\end{array}$ & Work & Company & None \\
\hline 4 & $\begin{array}{l}\text { Administrative } \\
\text { Department }\end{array}$ & $\begin{array}{c}\text { Responsible for company } \\
\text { administration logistics and } \\
\text { external relations }\end{array}$ & Responsible & External Relations & Work & Company & None \\
\hline 5 & $\begin{array}{l}\text { Administrative } \\
\text { Department }\end{array}$ & Responsible for publicity planning & Responsible & Publicity & Planning & Company & None \\
\hline 6 & $\begin{array}{l}\text { Administrative } \\
\text { Department }\end{array}$ & $\begin{array}{c}\text { Organize company project } \\
\text { management }\end{array}$ & Organize & Project & Management & Company & None \\
\hline 7 & $\begin{array}{l}\text { Administrative } \\
\text { Department }\end{array}$ & Responsible for file management & Responsible & File & Management & Company & None \\
\hline
\end{tabular}

A list of Development Department responsibilities are shown in Table IV.

TABLE IV. A LIST OF DEVELOPMENT DEPARTMENT RESPONSIBILITIES

\begin{tabular}{|c|c|c|c|c|c|c|c|}
\hline \multirow[b]{2}{*}{ No. } & \multirow[b]{2}{*}{$\begin{array}{l}\text { Responsibility } \\
\text { Subject }\end{array}$} & \multirow[b]{2}{*}{ Responsibility Basis } & \multicolumn{3}{|c|}{ Responsibility Describe } & \multirow[b]{2}{*}{ Range } & \multirow{2}{*}{$\begin{array}{c}\text { Joint } \\
\text { Implementation } \\
\text { of the Main Body }\end{array}$} \\
\hline & & & $\begin{array}{l}\text { Responsibilit } \\
\text { y Predicate }\end{array}$ & $\begin{array}{c}\text { Responsibility } \\
\text { Attributive }\end{array}$ & $\begin{array}{l}\text { Responsibility } \\
\text { Object }\end{array}$ & & \\
\hline 1 & $\begin{array}{c}\text { Development } \\
\text { Department }\end{array}$ & $\begin{array}{c}\text { Responsible for the administration } \\
\text { of this department }\end{array}$ & Responsible & Administration & Management & $\begin{array}{c}\text { Development } \\
\text { Department }\end{array}$ & None \\
\hline 2 & $\begin{array}{c}\text { Development } \\
\text { Department }\end{array}$ & $\begin{array}{c}\text { Organize company policy } \\
\text { research, development strategy } \\
\text { research }\end{array}$ & Organize & Policy & Research & Company & None \\
\hline 3 & $\begin{array}{l}\text { Development } \\
\text { Department }\end{array}$ & $\begin{array}{c}\text { Organize company policy } \\
\text { research, development strategy } \\
\text { research }\end{array}$ & Organize & $\begin{array}{l}\text { Development } \\
\text { Strategy }\end{array}$ & Research & Company & None \\
\hline 4 & $\begin{array}{l}\text { Development } \\
\text { Department }\end{array}$ & $\begin{array}{l}\text { Responsible for project pre - } \\
\text { feasibility study and project } \\
\text { declaration }\end{array}$ & Responsible & $\begin{array}{l}\text { Project Pre - } \\
\text { Feasibility }\end{array}$ & Research & Company & None \\
\hline 5 & $\begin{array}{l}\text { Development } \\
\text { Department }\end{array}$ & $\begin{array}{l}\text { Responsible for project pre- } \\
\text { feasibility study and project } \\
\text { declaration }\end{array}$ & Responsible & Project & Declaration & Company & None \\
\hline 6 & $\begin{array}{l}\text { Development } \\
\text { Department }\end{array}$ & $\begin{array}{l}\text { Responsible for capital operation } \\
\text { research and management of } \\
\text { company assets } \\
\end{array}$ & Responsible & $\begin{array}{l}\text { Capital } \\
\text { Operation }\end{array}$ & Research & Company & None \\
\hline 7 & $\begin{array}{l}\text { Development } \\
\text { Department }\end{array}$ & $\begin{array}{l}\text { Responsible for capital operation } \\
\text { research and management of } \\
\text { company assets }\end{array}$ & Responsible & $\begin{array}{l}\text { Company } \\
\text { Assets }\end{array}$ & Management & Company & None \\
\hline
\end{tabular}

\section{B. Department Responsibilities Conflict Evaluation}

Assuming three experts are invited to evaluate the department conflicts of the predicates, attributive and object respectively, on this basis,get the conflict evaluation conclusion between administrative department and development department of A company.

\section{1) Predicate Conflict Evaluation}

The results of the first expert's evaluation of the predicate conflict between administrative department and development department of A company are shown in Table V. 
TABLE V. THE RESULTS OF THE EXPERT'S EVALUATION OF THE PREDICATE CONFLICT

\begin{tabular}{|c|c|c|c|c|c|c|c|}
\hline $\begin{array}{c}\text { Administrativ } \\
\text { e Department } \\
\text { Development } \\
\text { Department }\end{array}$ & Lead & Responsible & Responsible & Responsible & Responsible & Organize & Responsible \\
\hline Responsible & General Conflict & Big Conflict & Big Conflict & Big Conflict & Big Conflict & General Conflict & Big Conflict \\
\hline Organize & General Conflict & General Conflict & General Conflict & General Conflict & General Conflict & Big Conflict & General Conflict \\
\hline Organize & General Conflict & General Conflict & General Conflict & General Conflict & General Conflict & Big Conflict & General Conflict \\
\hline Responsible & General Conflict & Big Conflict & Big Conflict & Big Conflict & Big Conflict & General Conflict & Big Conflict \\
\hline Responsible & General Conflict & Big Conflict & Big Conflict & Big Conflict & Big Conflict & General Conflict & Big Conflict \\
\hline Responsible & General Conflict & Big Conflict & Big Conflict & Big Conflict & Big Conflict & General Conflict & Big Conflict \\
\hline Responsible & General Conflict & Big Conflict & Big Conflict & Big Conflict & Big Conflict & General Conflict & Big Conflict \\
\hline
\end{tabular}

In the same way, we can get the results of the other two experts' evaluation of the predicate conflict between administrative department and development department of A company, according to the Eq.(1), we can get the predicate conflict evaluation results between administrative department and development department of A company, which are shown in Table VI.

TABLE VI. THE PREDICATE CONFLICT EVALUATION RESULTS

\begin{tabular}{|c|c|c|c|c|c|c|c|}
\hline $\begin{array}{c}\text { Administrati } \\
\text { ve } \\
\text { Depattment } \\
\text { Developnent } \\
\text { Department }\end{array}$ & Lead & $\begin{array}{c}\text { Resp } \\
\text { onsib } \\
\text { le }\end{array}$ & $\begin{array}{c}\text { Res } \\
\text { pons } \\
\text { ible }\end{array}$ & $\begin{array}{c}\text { Res } \\
\text { pon } \\
\text { sibl } \\
\text { e }\end{array}$ & $\begin{array}{c}\text { Respo } \\
\text { nsible }\end{array}$ & $\begin{array}{c}\text { Orga } \\
\text { nize }\end{array}$ & $\begin{array}{c}\text { Resp } \\
\text { onsi } \\
\text { ble }\end{array}$ \\
\hline Responsible & 0.5 & 1 & 1 & 1 & 1 & 0.5 & 1 \\
\hline Organize & 0.17 & 0.5 & 0.5 & 0.5 & 0.5 & 1 & 0.5 \\
\hline Organize & 0.17 & 0.5 & 0.5 & 0.5 & 0.5 & 1 & 0.5 \\
\hline Responsible & 0.5 & 1 & 1 & 1 & 1 & 0.5 & 1 \\
\hline Responsible & 0.5 & 1 & 1 & 1 & 1 & 0.5 & 1 \\
\hline Responsible & 0.5 & 1 & 1 & 1 & 1 & 0.5 & 1 \\
\hline Responsible & 0.5 & 1 & 1 & 1 & 1 & 0.5 & 1 \\
\hline
\end{tabular}

2) Department Responsibilities Conflict Evaluation

In the same way, we can get the Attribute Object and Range conflict evaluation results between administrative department and development department of A company. According to
Eq.(2), assume that $w_{1}=0.1, w_{2}=0.5, w_{3}=0.2$ and $W_{4}=0.2$, get the evaluation result of the department responsibilities conflict matrix elements between the administrative department and development department of A company, which are shown in Table VII.

TABLE VII. THE EVALUATION RESULT OF THE DEPARTMENT RESPONSIBILITIES CONFLICT MATRIX ELEMENTS

\begin{tabular}{|c|c|c|c|c|c|c|c|}
\hline $\begin{array}{c}\text { Administrative } \\
\text { Department } \\
\text { Development } \\
\text { Department }\end{array}$ & $\begin{array}{c}\text { Resp } \\
\text { onsi } \\
\text { bilit } \\
\text { y1 }\end{array}$ & $\begin{array}{c}\text { Res } \\
\text { pons } \\
\text { ibilit } \\
\text { y2 }\end{array}$ & $\begin{array}{c}\text { Resp } \\
\text { onsi } \\
\text { bilit } \\
\text { y3 }\end{array}$ & $\begin{array}{c}\text { Resp } \\
\text { onsi } \\
\text { bilit } \\
\text { y4 }\end{array}$ & $\begin{array}{c}\text { Resp } \\
\text { onsi } \\
\text { bility } \\
\mathbf{5}\end{array}$ & $\begin{array}{c}\text { Resp } \\
\text { onsib } \\
\text { ility6 } 6\end{array}$ & $\begin{array}{c}\text { Res } \\
\text { pons } \\
\text { ibilit } \\
\text { y7 }\end{array}$ \\
\hline Responsibility1 & 0 & 0 & 0.9 & 0 & 0 & 0 & 0 \\
\hline Responsibility2 & 0.37 & 0.7 & 0 & 0 & 0 & 0 & 0 \\
\hline Responsibility3 & 0.78 & 0.37 & 0 & 0 & 0 & 0 & 0 \\
\hline Responsibility4 & 0 & 0 & 0 & 0 & 0 & 0 & 0 \\
\hline Responsibility5 & 0 & 0 & 0 & 0 & 0 & 0 & 0 \\
\hline Responsibility6 & 0 & 0 & 0 & 0 & 0 & 0 & 0 \\
\hline Responsibility7 & 0 & 0 & 0 & 0 & 0 & 0 & 0 \\
\hline
\end{tabular}

According to Eq. (2) and Table 10, get the department responsibilities conflict table between the administrative department and development department of A company, which are shown in Table VIII.

TABLE VIII. THE DEPARTMENT RESPONSIBILITIES CONFLICT TABLE

\begin{tabular}{|c|c|c|c|c|c|c|c|c|c|c|}
\hline \multirow{2}{*}{ No. } & \multicolumn{4}{|c|}{ Responsibility Describe Of Administrative Department } & \multicolumn{4}{|c|}{ Responsibility Describe Of Development Department } & \multicolumn{2}{|c|}{$\begin{array}{c}\text { Conflict Evaluation } \\
\text { Conclusion }\end{array}$} \\
\hline & Predicate & Attributive & Object & Range & Predicate & Attributive & Object & Range & $\begin{array}{l}\text { Quantitati } \\
\text { ve }\end{array}$ & $\begin{array}{c}\text { Qualitativ } \\
\text { e }\end{array}$ \\
\hline 1 & Responsible & $\begin{array}{c}\text { Administratio } \\
\mathrm{n} \text { logistics }\end{array}$ & Work & Company & $\begin{array}{l}\text { Responsi } \\
\text { ble }\end{array}$ & $\begin{array}{c}\text { Administratio } \\
\mathrm{n}\end{array}$ & $\begin{array}{c}\text { Manageme } \\
\text { nt }\end{array}$ & $\begin{array}{c}\text { Development } \\
\text { Department }\end{array}$ & 0.9 & $\begin{array}{c}\text { Big } \\
\text { Conflict } \\
\end{array}$ \\
\hline 2 & Lead & $\begin{array}{c}\text { Company } \\
\text { development } \\
\text { strategy }\end{array}$ & Write & Company & Organize & $\begin{array}{c}\text { Development } \\
\text { strategy }\end{array}$ & Research & Company & 0.78 & $\begin{array}{c}\text { Big } \\
\text { Conflict }\end{array}$ \\
\hline 3 & Responsible & $\begin{array}{l}\text { Company } \\
\text { policies and } \\
\text { regulations }\end{array}$ & Formulate & Company & Organize & Policy & Research & Company & 0.7 & $\begin{array}{l}\text { General } \\
\text { Conflict }\end{array}$ \\
\hline 4 & Lead & $\begin{array}{c}\text { Company } \\
\text { development } \\
\text { strategy }\end{array}$ & Write & Company & Organize & Policy & Research & Company & 0.37 & $\begin{array}{c}\text { Small } \\
\text { Conflict }\end{array}$ \\
\hline 5 & Responsible & $\begin{array}{l}\text { Company } \\
\text { policies and } \\
\text { regulations }\end{array}$ & Formulate & Company & Organize & $\begin{array}{c}\text { Development } \\
\text { strategy }\end{array}$ & Research & Company & 0.37 & $\begin{array}{c}\text { Small } \\
\text { Conflict }\end{array}$ \\
\hline
\end{tabular}


From the table, we can see that there are 5 conflict items between the administrative department and the development department of A company, which there are 2 items are big conflict, 1 item is general conflict and 2 items are small conflict.

According to Eq.(3) and Eq.(4), the responsibility conflict quantitative conclusion between the administrative department and development department of A company is 0.34 , and the department responsibilities conflict qualitative conclusion between the administrative department and development department of A company is small conflict.

\section{REFERENCES}

[1] Xiaosong Li, Bin Lv, Zhenhua Xiao. The Evaluation of Weapon CivilMilitary Equipment Research and Production System. Beijing: National Defense Industry Press, 2014

[2] Qinghua Chen, Bin Lv, Xiaosong Li. Systems Engineering Theory and Practice. Beijing: National Defense Industry Press, 2011

[3] Bin Lv, Xiaosong Li, Qinghua Chen. Equipment Acquisition Risk Management Theory and Methods. Beijing: National Defense Industry Press, 2011 